\title{
Substitution of the most important and declining wild food species in south- east Burkina Faso
}

\author{
Anna Leßmeister ${ }^{1}$ *, Katharina Schumann¹, Anne Mette Lykke², Katja Heubach³, Adjima Thiombiano ${ }^{4}$, \\ Karen Hahn ${ }^{1}$ \\ ${ }^{1}$ Institute of Ecology, Evolution and Diversity, J.W. Goethe University, Frankfurt/Main, DE \\ ${ }^{2}$ Department of Bioscience, Aarhus University, Silkeborg, DK \\ ${ }^{3}$ Helmholtz Centre for Environmental Research - UFZ, Leipzig, DE \\ ${ }^{4}$ Department of Plant Biology and Physiology, University of Ouagadougou, Ouagadougou, BF \\ *Corresponding author. E-mail address: annalessmeister@gmx.de (A. Leßmeister)
}

\begin{abstract}
Summary: Wild plant species are important nutritious supplements to otherwise nutrient poor diets of rural populations in West Africa. Consequently, a decline of wild food species has a direct negative impact on the nutritional status of local households. In this study, we firstly investigated the preferred wild food species in south-east Burkina Faso, their perceived change in abundance as well as their contribution to wild food income. Secondly, we studied how these species might be substituted in times of species shortfall. Thirdly, we investigated the impact of socio-economic variables on the substitution choice. We conducted 155 household interviews in two villages and found 21 wild food species. With a contribution of almost $70 \%$ to wild food income, Vitellaria paradoxa and Parkia biglobosa were economically most important. All species were considered declining to some degree. The wide range of cited substitutes for the ten most important wild food species indicates a great knowledge on alternative plant species in the area. For the majority, the substitution choice did not depend on socio-economic characteristics. Cited as surrogate for several important wild food species, the native tree Balanites aegyptiaca was the most important substitute species. Many valued wild food species were substituted with other highly valued wild food species and therefore the decline of one species can lead to a shortfall of another substitute. Thus, even though our results suggest that people are able to counteract the decrease or absence of wild food species, growing decline of one species would concurrently increase the pressure on other native food species.
\end{abstract}

Key words: species decline, wild food, income, NTFPs, substitutes

\section{SUBSTITUTION DES PLUS IMPORTANTES ET DÉCROISSANTES ESPÈCES ALIMENTAIRES SAUVAGES AU SUD- EST DU BURKINA FASO}

Résumé: Des espèces de plantes sauvages constituent des compléments nutritionnels importants des régimes alimentaires pauvres en micronutriments des populations rurales en Afrique de l'Ouest. Par conséquent, le déclin des espèces alimentaires sauvages a un impact négatif direct sur la nutrition des ménages locaux. Dans cette étude, nous avons premièrement investigués les espèces alimentaires sauvages préférées dans le sud-est du Burkina Faso, leur changement perçu en abondance ainsi que leur contribution au revenu alimentaire sauvage. Deuxièmement, nous avons étudié comment ces espèces pourraient être substituées en période de pénurie des espèces. Troisièmement, nous avons examiné l'impact des variables socio-économiques sur le choix de substitution. En réalisant 155 interviews auprès des ménages dans deux villages, nous avons trouvé 21 espèces alimentaires sauvages. Avec une contribution d'environ $70 \%$ au revenu alimentaire sauvage, Vitellaria paradoxa et Parkia biglobosa sont économiquement les espèces les plus importantes. Toutes les espèces sont été considérées comme étant en déclin dans une certaine mesure. La vaste gamme de substituts cités pour les dix espèces les plus importantes indique une grande connaissance sur les espèces végétales alternatives dans la zone. Pour la plupart des plus importantes espèces alimentaires sauvages, le choix de substitution ne dépend pas des caractéristiques socio-économiques. Cité comme représentant pour plusieurs espèces importantes alimentaires sauvages, l'arbre local Balanites aegyptiaca est la plus importante espèce de substitut. De nombreuses espèces alimentaires sauvages évaluées sont substitués par d'autres espèces alimentaires sauvages à grande valeur et dont le déclin d'une espèce peut conduire à un déficit d'un autre substitut. Ainsi, même si nos résultats révèlent que les populations sont potentiellement capables de contrecarrer la diminution ou l'absence des espèces alimentaires sauvages, le déclin croissant d'une seule espèce pourraient simultanément augmenter la pression sur les autres espèces alimentaires locales.

Mots clés: PFNLx, déclin d'espèce revenu, aliment sauvage, substituts

\section{SUBSTITUIERUNG DER WICHTIGSTEN UND ZURÜCKGEHENDEN ESSBAREN WILDPFLANZEN IN SÜDOST BUR- KINA FASO}

Zusammenfassung: Essbare Wildpflanzen stellen wichtige Nahrungsergänzungen, zu einer ansonsten nährstoffarmen Ernährung ländlicher Bevölkerung in West Afrika, dar. Aus diesem Grund hat der Rückgang von essbaren Wildpflanzen direkte negative Auswirkungen auf den Nährstoffhaushalt lokaler Haushalte. In dieser Studie dokumentierten wir erstens die bevorzugten essbaren Wildpflanzen in Südost Burkina Faso, ihre wahrgenommene Abundanzveränderung und ihren Anteil am essbaren Wildpflanzen-Einkommen. Wir untersuchten zweitens die Substituierung dieser Arten in Zeiten von Artenknappheit und drittens den Einfluss von sozio-ökonomischen Variablen auf die Auswahl der Substitute. Mit 155 Haushaltsbefragungen in zwei Dörfern erhielten wir insgesamt 21 genutzte essbare Wildpflanzen. Mit einem Beitrag von rund 70\% zum essbaren 
Wildpflanzen-Einkommen waren Vitellaria paradoxa und Parkia biglobosa ökonomisch die wichtigsten Arten. Alle Arten wurden als mehr oder weniger zurückgehend eingestuft. Die hohe Anzahl genannter Substitute für die zehn wichtigsten essbaren Wildpflanzen zeigt ein umfassendes Wissen bezüglich alternativer Wildpflanzen in dem Untersuchungsgebiet. Die Substitutauswahl ist für die Mehrheit der essbaren Wildpflanzen nicht abhängig von sozio-ökonomischen Merkmalen. Der heimische Baum Balanites aegyptiaca wurde für mehrere essbare Wildpflanzen als Substitut genannt und war damit die wichtigste Substitutart. Viele der bevorzugten essbaren Wildpflanzen wurden mit anderen bevorzugten essbaren Wildpflanzen substituiert. Der Rückgang einer Art kann somit zum Wegfall eines anderen Substitutes führen. Obwohl unsere Ergebnisse suggerieren, dass die Menschen dem Rückgang oder Fehlen von essbaren Wildpflanzen entgegenwirken können, würde ein zunehmender Rückgang einer Art gleichzeitig den Druck auf andere heimische Wildpflanzen erhöhen.

Schlagworte: Artenrückgang, Einkommen, Nichtholzprodukte, Substitute, essbare Wildpflanzen

\section{INTRODUCTION}

In West Africa, livelihoods of rural people are highly dependent on non-timber forest product (NTFP)-providing plant species for subsistence and cash income (AgRAWAL et al. 2013). NTFPs include all products other than timber derived from forests and agroforestry systems, such as fruits, nuts, vegetables, fish, game, medicinal plants, bark, gum, leaves, grasses and small wood products like firewood and chew-sticks (BELCHER 2003; CIFOR 2011). They serve i.e. as source for firewood, food, medicine, construction and fodder and therefore provide a safety net in times of income shortages trough i.e. crop shortfalls (cf. MALLESON et al. 2014; ShackLETON \& PANDEY 2014). The extraction of NTFPs is particularly attractive for the very poor since NTFPs are open or semi-open access resources that do not require expensive equipment for harvesting (ANGELSEN and WUNDER 2003). In northern Benin, HeUBACH et al. (2013) identified 90 and VodouHê et al. (2009) 76 plant species that are locally used for various purposes. In the Sahel of Burkina Faso, LYKKE et al. (2004) found 56 woody species of multipurpose value to rural livelihoods. The food provision of those species is particularly important to complement diets in quantity and to add minerals and vitamins to a generally monotonous and nutrient poor diet. For this purpose, edible fruits, flowers, seeds and leaves are collected from parkland trees in fallows and fields and from woody species in woodlands.

A shortfall of NTFPs can severely affect household livelihoods in terms of food security, energy supply, medical care, animal husbandry, and financial means. Short-term NTFP shortage might be caused by low rainfall and/or depleted stocks before the next harvest season. However, human population growth increases the pressure on cultivated land in the long term. It leads to expanded agricultural land and a shortening of fallow stages, causing species loss due to lacking regeneration of the natural vegetation. Several studies in West Africa anticipate serious shifts in climatic conditions and land use patterns which are likely to affect water resources and soil fertility (COOPER et al. 2008; SALA et al. 2000) and thus, the provision of non-timber forest products (NTFPs). A recent investigation conducted in Benin, projected a decrease in regional occurrence and, thus, obtained economic returns, up to $50 \%$ in 2050 for key NTFP providing tree species (HeUbes et al. 2012).

Since Burkina Faso belongs to the poorest countries on earth (UNDP 2014), coping with these predicted negative changes will be a major challenge to the rural poor. It is therefore of particular importance to investigate which species are particularly declining, how they contribute to household income and whether and how a projected decrease could be counteracted to mitigate the socio-economic consequences.
As the coping capacity of households is particularly conditioned by their socio-economic characteristics (PATTANAYAK \& SILLS 2001; TURNER et al. 2003) it is furthermore crucial to investigate whether all households have similar strategies to replace wild food species or whether they differ with regard to to social and spatial differentiations (e.g. village, ethnicity, household income), in order to develop management strategies that are reliable for a specific region. For example, investigating valuation and use preferences of wild plant species in Benin and Burkina Faso, SEgnON \& ACHIGAN-DAKo (2014) and ZizKA et al. (2015) showed that location and ethnicity have an effect. Further, in terms of NTFP income KALABA et al. (2013) showed that a household's property level determines coping opportunities: poorer households enhanced their engagement in NTFP extraction to cope with shocks considerably stronger than wealthier households.

Understanding local systems of supply and dependencies is crucial to support local decision-makers in enhancing rural communities' adaptive capacities to environmental change. In West Africa, a number of current studies investigated plant species valuation, use and economic contribution, but there is a need to study compensations and coping strategies in case of species' shortfall.

Consequently, we focused on the substitution of wild food species. In a first step, we identified the most valued wild food species, and since their contribution to daily diet is their most important usage, we focused our analysis accordingly. Secondly, the observed species decline and its contribution to wild food income was studied. Thirdly, we identified the substitutes used by rural households to cope with a seasonal/temporary absence of NTFPs.

In our study, we thus seek to answer the following questions:

1. What are the most important wild food species and how do they contribute to household income?

2. Which species are observed to be declining?

3. How are these wild food species substituted in times of species shortfall?

4. Does the substitution preference depend on socio-economic characteristics?

\section{Methods}

\subsection{Study villages}

The investigations were conducted in the north Sudanian zone in south-east Burkina Faso. We selected two study 
villages (Nagré and Kompienbiga) lying $70 \mathrm{~km}$ apart (Fig. 1). These villages were chosen due to their similar characteristics in terms of population size (around 1000-1300 households), distance to the next urban centre $(30 \mathrm{~km}$ to Fada N'Gourma and $10 \mathrm{~km}$ to Pama) and the constitution of main ethnic groups. Furthermore, the availability of a school, hospital, piped water and a local market, but a lack of electricity, is common to both villages.

Kompienbiga is situated in a more humid zone than Nagré. Thus, we obtained information from two climatically differing areas.

The vegetation is composed of different savanna types, woodland, tree, shrub and grass savanna. The typical far- ming system is characterised by alternating cycles of cultivation and fallow periods, managed by subsistence farmers. Useful tree species are spared from field clearing. Agriculture and extensive livestock breeding (e.g., cattle, goat, sheep and chicken) are the main income sources in the region.

\subsection{Ethnic groups}

The three main ethnic groups located in the study area are the two agriculturalist societies, Gourmantché and Mossi and the seminomadic pastoralists, Fulani. The Gourmantché are the dominant, autochthon people in the area. The Mossi, who are the most dominant ethnic group in the country ori-

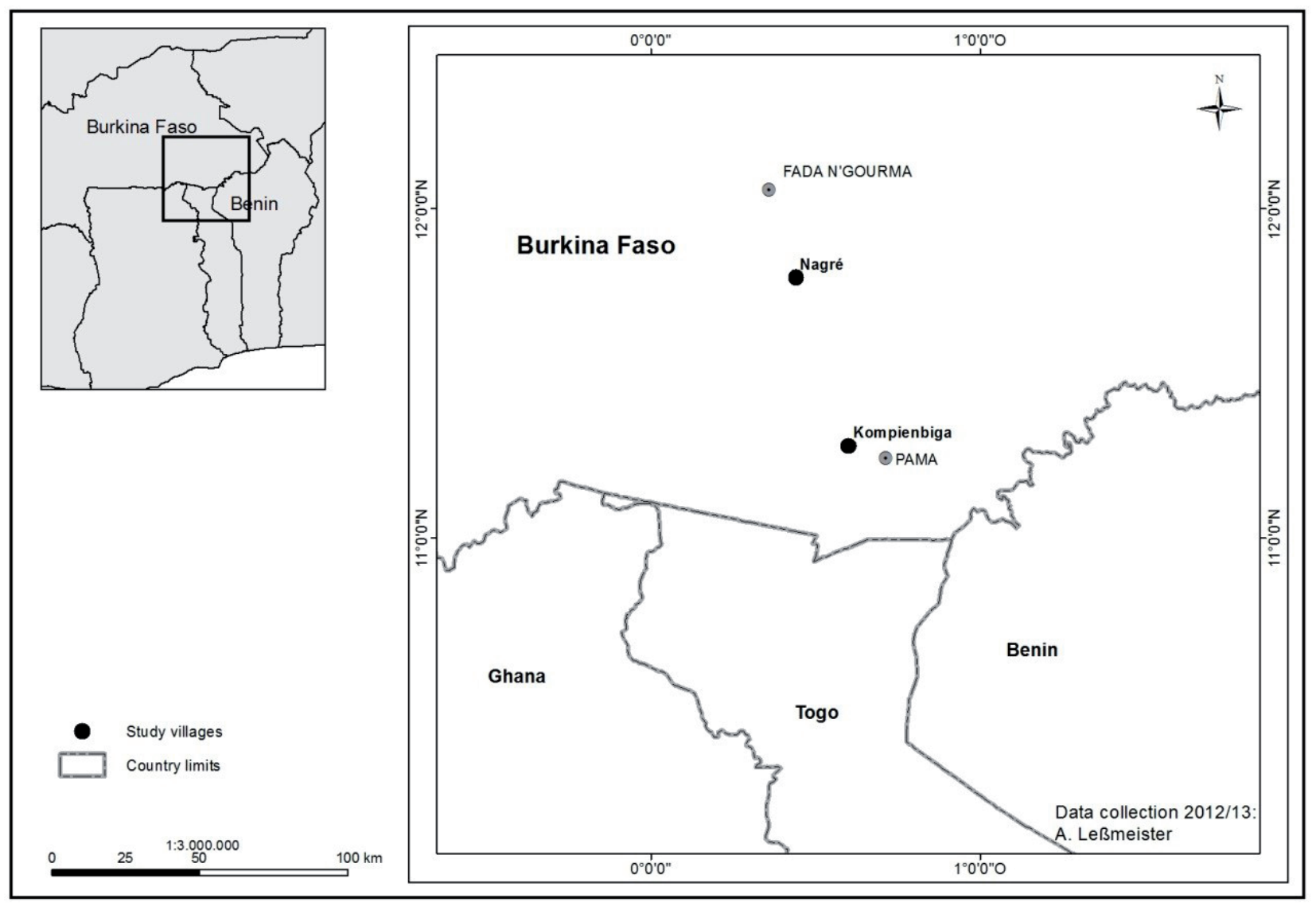

Fig. 1 : Location of the study villages in south-east Burkina Faso / Localisation des villages de l'étude au Sud-est du Burkina Faso.

ginally living in the centre of Burkina Faso, migrated to the study area (CIA 2009). The Fulani also migrated to the area from the countries' northern part.

\subsection{Data collection and analysis}

In our study, we followed the interview approach and methods as implemented in northern Benin by Heubach et al. (2011). We conducted a total of 155 structured household surveys using both closed and open questions at the end of the harvesting period between November 2012 and April 2013. In both villages, a minimum of 25 interviews within each ethnic group was considered. Households were chosen by stratified random methods according to their ethnicity.
Interviews were conducted separately with the household head (always a man) and his first wife (households are often polygamous). Women cited the most valued wild food species with the plant parts used (i.e. flowers, fruit, leaves) and the form of use (i.e. raw, sauce, drink). Each species mentioned was ranked according to a change category ( $1=$ increasing, $0=$ no change, $-1=$ decreasing, $-2=$ very decreasing) and reasons for the species decline were asked using open questions. To calculate income share values of wild food, women additionally provided information on the collection and consumption of the cited wild food species in their household within the year 2012 as well as on prices at the local market. Subsequently, they were asked to report substitutes for the wild food species when they are seasonally/ 
temporary unavailable. Each woman mentioned one substitute for one wild food species. Aiming at relating substitution of wild food species to socio-economic characteristics, we additionally collected data regarding household income, age and education of the household head and farmland size owned. This information was provided by the household head. Furthermore, we conducted market interviews at village markets to double check and complement prices. To ensure comparability between households of different sizes and compositions we conducted an income adjustment. We applied an OECD modified equivalence scale considering types of household members (men, women, children) reflecting the nutrition need and the number of household members (household size) (DEATON 1982). The result is an adjusted income per adult equivalent unit (aeu) allowing comparability.

For species mentioned by less than $5 \%$ of the respondents, we did not include change and income share values. The interviews were conducted in local languages with an interpreter.

To study whether the choice in substitution was related to socio-economic variables, the mentioned substitutes were tested against the following variables using a chi-square test: Village origin (Nagré; Kompienbiga), ethnicity (Gourmantché; Mossi; Fulani), age (4 categories, <35, 36-45, 46$55,>56$ ), education (yes; no), income groups ( 3 terciles 'poor', 'medium' and 'less poor'), and farmland size $(<4$ ha; $>4$ ha).

The average household size of both studied villages was composed of seven to nine members and the household heads were, on average, in their mid-forties. For all ethnic groups, the education level was very low. The agriculturalists Gourmantché and Mossi owned more farmland than the pastoralists (Fulani). Household income was higher in the village Nagré for all ethnic groups compared to Kompienbiga. The autochthonous Gourmantché in Nagré had the highest household income.

\section{Results}

\subsection{Wild food species importance}

Respondents mentioned 21 wild food species, 20 woody and one herbaceous species (Corchorus olitorius), collected for subsistence consumption (Table 1). Only one plant part, i.e. the fruits, leaves, seeds or flowers, was used of the majority of the stated plant species as food supply. For three species (Vitellaria paradoxa, Adansonia digitata, Annona senegalensis) two plant parts were used (Table 1). Vitellaria paradoxa was the most important wild food species as it was mentioned by nearly all respondents. With a contribution of $43 \%$ to the households' wild food income $V$. paradoxa was also the most important economic food species. Lannea microcarpa was the second most important wild food species in terms of citations, but only gave a very little share to households' wild food income. All other species were only stated by less than $50 \%$ of the respondents. Even though Parkia biglobosa was only mentioned by $45 \%$ of the respondent, it was economically important as it contributed with a high share $(26 \%)$ to households' wild food income.
Five species (Corchorus olitorius, Piliostigma reticulatum, Piliostigma thonningii, Sclerocarya birrea, Vitex doniana) were only mentioned by one informant.

\subsection{Species decline}

According to the respondents, all wild food species were considered declining, but the degree differed (Table 1). Vitellaria paradoxa, Parkia biglobosa, Balanites aegyptiaca were classified as very strongly declining species with a value between 1,5 and 2 .

Lannea microcarpa, Ziziphus mauritiana, Detarium microcarpum, Diospyros mespiliformis, Adansonia digitata, Gardenia erubescens, Ximenia americana were classified as strong declining (between 1,5 and 1,7). Tamarindus indica, Bombax costatum and Annona senegalensis were rated as declining between 1.1 and 1.4. The free cited reasons for decline were relatively homogenous. The most cited reason for all species was "removal of seedlings and saplings", followed by "excessive cut" and "shortage of rainfall".

\subsection{Substitutes}

For substitute analysis, we only considered species that were cited at least by 20 respondents as useful food species, giving a total of 10 species (see Table 1). Interviews revealed that the number of substitutes differed widely between the 10 studied wild food species. While the fruits of Lannea microcarpa and the seeds of Parkia biglobosa could be substituted by 14 other products, the calyxes of Bombax costatum were replaceable by only three products (Fig. 2). The other seven studied wild food species were substituted by 8 to 11 products. For all target species, one to three substitutes were mentioned by a high proportion of interviewed women, while the other substitutes were mentioned by very few respondents.

Very few respondents $(<10 \%)$ stated that they had no substitution for the 10 studied woody species. For all studied species, native woody species were the most cited substitutes (in total 21 species), while wild herbaceous (1 species) and cultivated plants ( 2 species) were very rarely mentioned (Fig. 2). Many woody species were mentioned several times as substitutes. The fruits of Balanites aegyptiaca were the most important substitutes for four studied species. The substitutes for each of the 10 most important woody species are described in detail in the following:

Interviewed women reported to replace the fruits of Vitellaria paradoxa by fruits of 10 native woody species (Fig. 2). By far the most cited substitutes were the fruits of L. microcarpa, followed by the fruits of Diospyros mespiliformis. Correspondingly, the fruits of Vitellaria paradoxa were the most cited substitutes for the fruits of L. microcarpa. The fruits of $D$. mespiliformis and Ziziphus mauritiana were also frequently cited as substitutes of $L$. microcarpa, while the other 11 cited substitutes (all woody species) were mentioned by very few respondents.

The seeds/ fruits of P. biglobosa and Z. mauritiana were substituted by 14 and 11 products, respectively (all woody species). For both species, the fruits of B. aegyptiaca were the most important substitutes. The fruits of $Z$. mauritiana 
Table 1: List of all cited wild food species by 155 respondents, percentage citation of species, used plant part, form of use and estimated change of the species $(0=$ no decline, $-1=$ decline, $-2=$ strong decline $)$. / Liste de toutes les espèces alimentaires sauvages cités by 155 répondants, pourcentage de citation des espèces, partie de la plante utilisée, forme d'utilisation et variation estimative des espèces $(0=$ pas de déclin, $-1=$ déclin, $-2=$ fort déclin $)$

\begin{tabular}{|c|c|c|c|c|c|c|}
\hline No. & Species & $\begin{array}{l}\text { Number } \\
\text { of cita- } \\
\text { tions in \% }\end{array}$ & Plant part & Form of use & Change & $\begin{array}{l}\text { Wild food in- } \\
\text { come per aeu* } \\
\text { in } \%\end{array}$ \\
\hline \multirow{2}{*}{1} & \multirow{2}{*}{ Vittelaria paradoxa } & \multirow{2}{*}{97} & fruit & raw & \multirow{2}{*}{-1.85} & \multirow{2}{*}{43} \\
\hline & & & seeds & cooking oil & & \\
\hline 2 & Lannea microcarpa & 79 & fruit & raw & -1.53 & 3 \\
\hline 3 & Parkia biglobosa & 45 & seeds & sauce & -1.73 & 26 \\
\hline 4 & Ziziphus mauritiana & 44 & fruit & raw & -1.56 & 1 \\
\hline 5 & Tamarindus indica & 38 & fruit & sauce, drink, raw & -1.36 & 7 \\
\hline 6 & Balanites aegyptiaca & 34 & fruit & raw & -1.91 & 1 \\
\hline 7 & Detarium microcarpum & 27 & fruit & raw, cooked & -1.65 & 1 \\
\hline 8 & Diospyros mespiliformis & 21 & fruit & raw & -1.81 & 1 \\
\hline \multirow{2}{*}{9} & \multirow{2}{*}{ Adansonia digitata } & \multirow{2}{*}{18} & leaves & sauce & \multirow{2}{*}{-1.51} & \multirow{2}{*}{7} \\
\hline & & & fruit & raw, drink, sauce & & \\
\hline 10 & Bombax costatum & 14 & calyx & sauce & -1.33 & 9 \\
\hline 11 & Gardenia erubescens & 6 & fruit & raw & -1.54 & 0.1 \\
\hline \multirow{2}{*}{12} & \multirow{2}{*}{ Annona senegalensis } & \multirow{2}{*}{5} & flower & sauce & \multirow{2}{*}{-1.10} & \multirow{2}{*}{0.5} \\
\hline & & & fruit & raw & & \\
\hline 13 & Ximenia americana & 5 & fruit & raw & -1.58 & 0.1 \\
\hline 14 & Strychnos spinosa & 4 & leaves & sauce & NA & NA \\
\hline 15 & Vitex simplicifolia & 3 & fruit & raw & NA & NA \\
\hline 16 & Sarcocephalus latifolius & 1 & fruit & raw & NA & NA \\
\hline 17 & Corchorus olitorius & 1 & leaves & sauce & NA & NA \\
\hline 18 & Piliostigma reticulatum & 1 & leaves & sauce & NA & NA \\
\hline 19 & Piliostigma thonningii & 1 & leaves & sauce & NA & NA \\
\hline 20 & Sclerocarya birrea & 1 & fruit & raw & NA & NA \\
\hline 21 & Vitex doniana & 1 & fruit & raw & NA & NA \\
\hline
\end{tabular}

* aeu: adult equivalent unit (explanation see 2.3) / aeu: unité équivalente adulte (explication voir 2.3)

were mostly cited as substitutes for the fruits of B. aegyptiaca. There were 11 woody species used as substitutes for B. aegyptiaca.

For Tamarindus indica, women reported 8 products as substitutes. The exotic lemon tree (Citrus $\times$ limon $)$ and the fruits of the local shrub species Piliostigma reticulatum and P. thonningii were the most important substitutes.

The fruits of Detarium microcarpum and D. mespiliformis could be substituted by 11 and 9 products, respectively (all woody species). For both species, the fruits of B. aegyptiaca were the most important substitutes. To replace the fruits of D. microcarpum and D. mespiliformis the fruits of $D$. mespiliformis and Z. mauritiana, respectively, were also favored.

The fruits and leaves of Adansonia digitata could be substituted by 11 products ( 9 woody species, one herbaceous species, and one cultivated plant). More than half of the respondents declared that the leaves of $A$. digitata could be substituted by the calyxes of $B$. costatum. The seeds of $P$. biglobosa and the leaves of the herb Corchorus olitorius were the second and third most important substitutes.
The calyxes of $B$. costatum were replaceable by only 3 products ( 2 woody species, 1 cultivated plant). Most respondents stated that they use the leaves of $A$. digitata as substitutes of the calyxes of $B$. costatum. The cultivated vegetable lady fingers (Abelmoschus esculentus) was the second most cited substitute.

\subsubsection{Relation of substitution choice and socio-economic- characteristics}

For most of the ten wild food species the tested variables (ethnicity, village, age, education, income and farmland size) did not show an influence on the choice in substitution. However, village had a significant influence on the substitution of three species and ethnicity, income, and farmland size of one studied species (Fig. 3). In contrast, age and education did not influence the choice in substitution of the 10 studied woody species.

The substitution of the seeds from Parkia biglobosa differed significantly between the three ethnic groups $\left(\mathrm{X}^{2}=33.5, \mathrm{p}=\right.$ 0.044). The Gourmantché (13 substitutes) mentioned twice as many substitutes as the Mossi (7 substitutes) and Fulani (6 substitutes). For the Gourmantché, the fruits of Vitellaria 


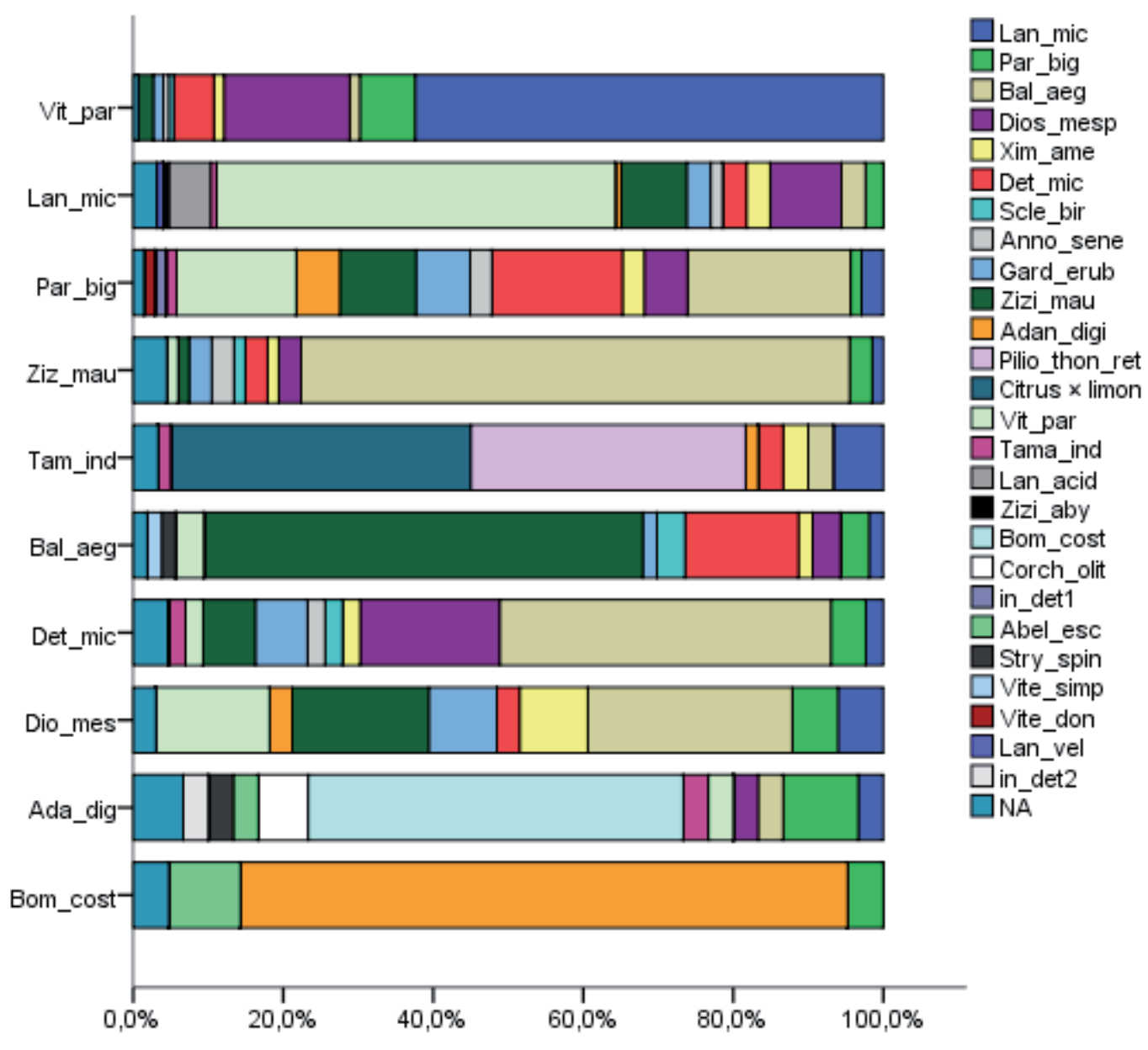

Fig. 2: Dietary substitutes for the fruits of the 10 most important wild food species / Substituts nutritionnels pour les fruits des 10 plus importantes espèces alimentaires sauvages. Vit_par = Vitellaria paradoxa, Lan_mic = Lannea microcarpa, Par_big = Parkia biglobosa, $\mathbf{Z i z}_{\mathbf{z}} \mathbf{m a u}=$ Ziziphus mauritiana, Tam ind = Tamarindus indica, Bal aeg = BaTanites aegyptiaca, Det mic $=$ Detarium microcarpum, Dio $\mathbf{m e s}=$ Diospyros mespiliformis, Ada dig = Adansonia digitata, Bom $^{-} \mathbf{c o s t}=$ Bombax costatum, $\mathbf{X i m}$ àme $=$ Ximenia americana, Scle bir

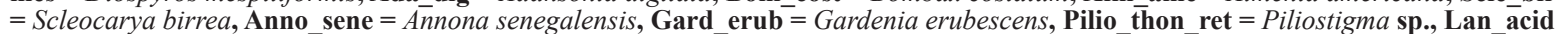

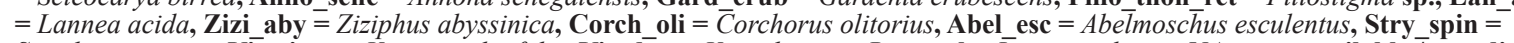
Strychnos spinose, Vit_simp = Vitex simplicifolia, Vit_don = Vitex doniana, Lan_vel = Lannea velutina, NA = not available $/$ non disponible, in_det $=$ species not identified $/$ espèce non identifiée.

paradoxa were the most important substitutes, while fruits of Detarium microcarpum and Balanites aegyptiaca were the most important substitutes for the Mossi and Fulani, respectively.

Income significantly influenced the choice in substitution of fruits from $V$. paradoxa $\left(\mathrm{X}^{2}=29.0, \mathrm{p}=0.049\right)$. The poor and medium income group cited more substitutes in total (6 and 8 , respectively) than the less poor income group (4). The fruits of Lannea microcarpa were the most important substitutes for all three income groups. The fruits of Diospyros mespiliformis were the second most important substitutes for the poor and medium income group, while the seeds of $P$. biglobosa were the second most cited substitute of the less poor group.

Village origin significantly influenced the choice in substitution of fruits from $V$. paradoxa $\left(\mathrm{X}^{2}=42.6, \mathrm{p}=0.000\right)$, Tamarindus indica $\left(\mathrm{X}^{2}=15.1, \mathrm{p}=0.035\right)$, and L. microcar$p a\left(\mathrm{X}^{2}=33.5, \mathrm{p}=0.044\right)$. People from the southern village Kompienbiga knew twice as many substitutes (10) for the fruits of $V$. paradoxa than those of the northern village
Nagré (5). Contrary to $V$. paradoxa, people from Nagré knew more substitutes of T. indica (7) and L. microcarpa (10) than people from the village Kompienbiga (5 and 9, respectively). While Citrus $\times$ limon was the main substitute of T. indica in Nagré, people from Kompienbiga mostly cited the fruits of the native shrubs Piliostigma reticulatum and P. thonningii as substitute.

Farmland size only significantly influenced the substitution choice of the fruits from L. microcarpa. People holding more farmland for cultivation ( $>4 \mathrm{ha}$ ) more often cited the fruits of $V$. paradoxa as substitutes than people owing less farmland $(<4$ ha).

\section{Discussion}

\subsection{Wild food species}

The ten wild food species identified as most important for rural communities in south-east Burkina Faso have also been found most useful in other regions of West Africa, 


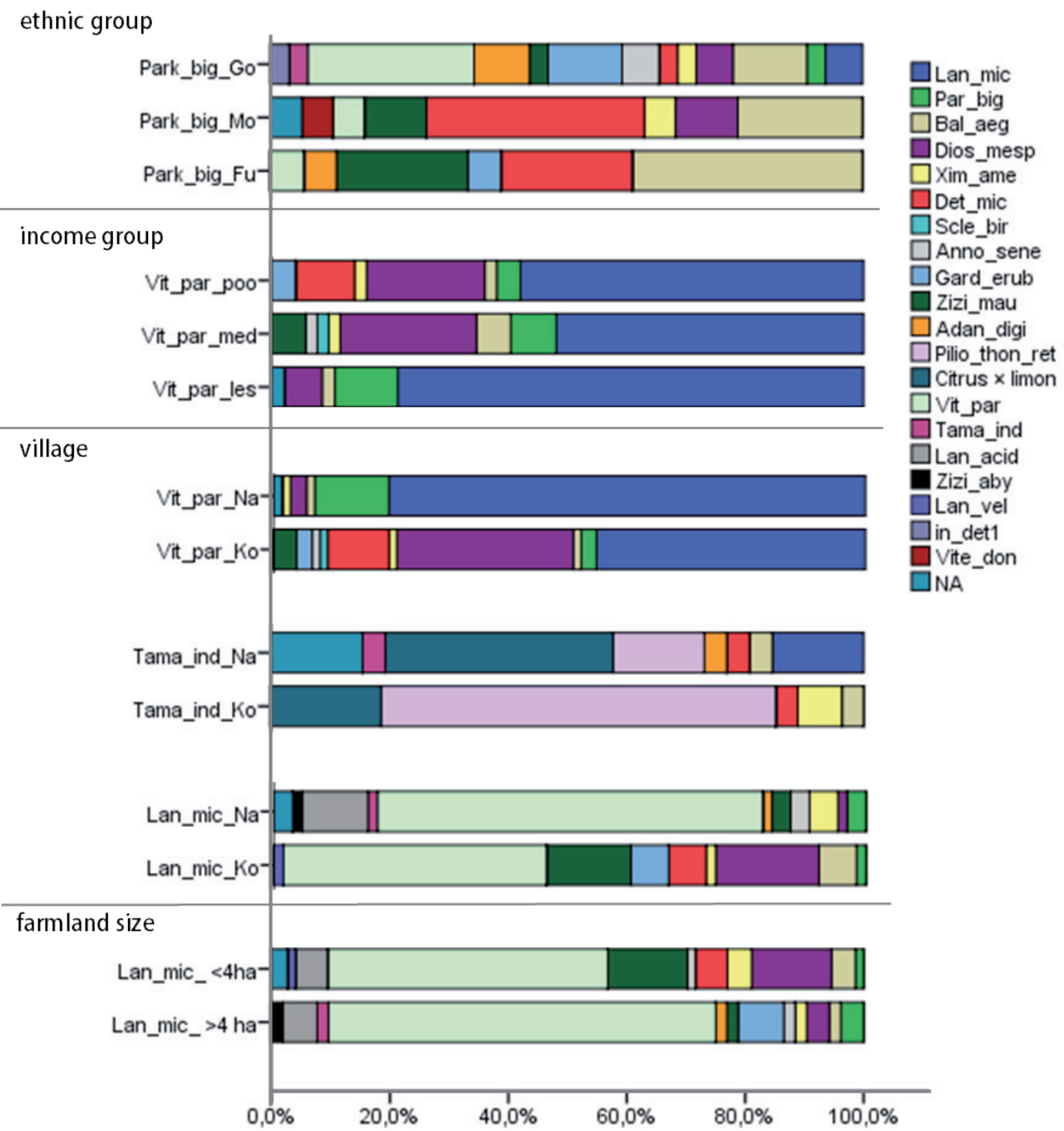

Fig. 3: Differences in substitution of wild food species between ethnic and income groups, villages and farmland size. / Différences dans la substitution des espèces alimentaires sauvages entre groupes ethnique et de revenu, les villages et la taille des terres agricoles. Vit_par =Vitellaria paradoxa, Lan_mic = Lannea microcarpa, Park_big = Parkia biglobosa, Tam_ind = Tamarindus indica, Ziz_mau = Ziziphus mauritiana, Bal_aeg = Bătanites aegyptiaca,, Det_mic $=$ Detarium microcarpum, Dios_mesp = Diospyros mespiliformis, $\overline{\mathbf{A} d a n}$ digi $=$ Adansonia digitata, $\mathbf{X}$ Xim_ame $=$ Ximenia americaña, Scle_bir $=$ Scleocarya birrea, Anno_sene $=$ Annona senegalensis, Gard_erub

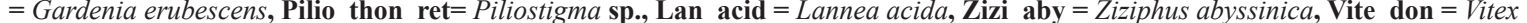
doniana, Lan_vel $=$ Lannea velutina, $\mathbf{G o}=$ Gourmantché, $\mathbf{M o}=$ Mossi, $\mathbf{F u}=$ Fulani, $\mathbf{p o o}=$ poor $/$ pauvres, med $=$ medium $/ \mathbf{m o y e n}, \mathbf{l e s}=$ less poor $/$ moins pauvres, $\mathrm{Na}=$ Nagré, Ko $=$ Kompienbiga, $<4 \mathrm{ha}=$ farmland size less than $4 \mathrm{ha} /$ taille de terres agricoles moins de $4 \mathrm{ha}$, $>4 \mathrm{ha}=$ farmland size more than $\mathbf{4} \mathrm{ha} /$ taille des terres agricoles de plus de $\mathbf{4} \mathrm{ha}, \mathrm{NA}=$ not available $/$ non disponible, in_det $=$ species not identified / espèces non identifiées.

showing their supra-regional importance. For instance, SoP et al. (2012) found six, LYKKe et al. (2004) and HeuBACH et al. (2013) five of our ten species as the most useful wild food species in the Sahelian and Soudanien zones. In all studies, woody species are the best known, valued and used wild food supplier, while similarly to our study, herbs are of minor importance. In northern Benin, Vitellaria parado$x a$ and Parkia biglobosa are the two most valued wild food use species (Heubach et al. 2013). Furthermore, the total number of 29 identified useful wild food species is in accordance with our findings.

Of the ten most useful food species, the fruits were by far the most valuable plant parts. Fruits from wild woody plants are inter alia especially important as supplement for crops, due to their maturity outside the crop harvest season (LYKKE et al. 2004). The three most valued wild food species ( Vitellaria paradoxa, Lannea microcarpa, Parkia biglobosa) as well as Adansonia digitata and partly also Tamarindus indica and Bombox costatum are typical parkland trees, left on the fields during field clearings (HAARMEYER et al. 2013; Schreckenberg 1999; Schumann et al. 2012).

The by far most important wild food species $V$. paradoxa has been investigated in various studies. Vitellaria parado$x a$ seeds supply important cooking oil, commonly known as shea butter, for local livelihoods. It serves as the most important source of fat for rural people. Additionally, the fruit can be eaten raw. The very high share of $V$. parado$x a$ to wild food income in our study was similarly found 
by Pouliot (2012), with $V$. paradoxa contributing $12 \%$ to total household income in south western Burkina Faso. The fruits of the second most mentioned wild food species L. microcarpa, commonly known as african grape or wild grape, are eaten raw or produced as juice (HAARMEYER et al. 2013). Since this use is less important to the local cooking (compared to $V$. paradoxa), they only contributed with a small share of $3 \%$ to wild food income, which could additionally be due to a considerably lower price on local markets as well as on lower total amounts harvested. Parkia biglobosa, known as the African locust bean tree, contributed considerably to wild food income of local households with $26 \%$. Its' fermented seeds, called soumbala, are an essential and typical product for cooking sauces in the region. Due to its' high protein and fat content, soumbala is an important supplement to staple foods in rural areas of West Africa (KRONBORG et al. 2014). Other species that contributed considerably to alimentation and wild food income of rural livelihoods were $T$. indica, $A$. digitata and B. costatum. The tamarind (T. indica) and the baobab (A. digitata) are used for sauces, porridge, as drinks and both contain considerable amounts of proteins and vitamin C (GEBAUER et al. 2002; JAMA et al. 2008). B. costatum, the silk cotton tree, is highly valued for the local cuisine. The calyxes were used to prepare a highly valued sauce. Even though it was less often mentioned as important wild food species its contribution to wild food income was appreciable.

Compared to studies with predefined species lists (LYKKE et al. 2004) our study revealed a considerably lower total number of wild food species. The disadvantage of the free listening method is that species less often used are underrepresented in the interview. Herbaceous species, for example, were rarely mentioned in our study. Since our surveys were conducted during the dry season, in which herbaceous species are not/rarely available, respondents might have forgotten species that are only available during the rainy season.

\subsection{Species decline}

Respondents described all wild food species as declining to a certain degree raising concern about the maintenance of these species in the future. This result is in accordance with LYKKE et al. (1998, 2004), who studied species decline in western Senegal and northern Burkina Faso. This declining trend is caused by current land use intensifications (e.g. expansions of agricultural land, shortening of fallow periods), leading to a reduction of suitable habitats and an insufficient time for regeneration of native species during the fallow period (NACOULma et al. 2011). The decline of these useful species might in addition be caused by a high exploitation rate (WEZEL \& RATH 2002) and unsustainable way of harvesting. Parkia biglobosa, for example, produces enough seedlings and saplings for reproduction but is sensitive to fire (LYKKE 1998) and is therefore highly affected by field clearings trough fire and population pressure.

The observed very strong decline of the by far most economically important wild food species Vitellaria paradoxa and P. biglobosa ( $70 \%$ of wild food income) supposes serious impacts on rural household incomes in the future, which is in concordance with findings of Heubes et al. (2012). Both species are mainly preserved on cultivated lands. However, saplings are considerably cut back and reduced during field clearings, leading to an ageing of species' population (DJosSA et al. 2008; SCHrECKENBERG 1999).

\subsection{Substitutes}

The wide range of species mentioned as substitute for the wild food species showed that knowledge on alternative plant uses is high.

The list of substitute species contained almost exclusively native plant species and was very similar to the original cited wild food species list. Only three additional wild tree species were cited as substitutes (Lannea acida, Lannea velutinum, Ziziphus abyssinica). Interestingly, cultivated products, such as peanut oil as a substitute for shea butter (Vitellaria paradoxa) or other purchased products, such as Maggi as substitute for soumbala (Parkia biglobosa), were not cited. This suggests that these products are too costly for the interviewed households. In contrast, most valued wild food species were substituted with other highly valued wild food species. This indicates that many species were both, primary chosen wild food supplier as well as substitutes in case of shortfall of other primary wild food species. For example, the most cited substitute for the fruits of V. parado$x a$ were the fruits of Lannea microcarpa and the other way around. The same holds true for the fruits of Ziziphus mauritiana and Balanites aegyptiaca as well as for the leaves of Adansonia digitata and the calyxes of Bombax costatum. Therefore, the need to protect and sustainable manage native wild food species in woodland savanna and on fields/ fallows becomes even more apparent. The loss of one species would additionally mean a loss of substitution alternatives of other wild food species.

B. aegyptiaca seems to be the most important substitute as it was by far the most frequently cited substitute and was mentioned as major surrogate for four of the ten wild food species. Its importance as substitute might be explained by the fact that $B$. aegyptiaca, known as the desert date, is a drought tolerant, typical Sahelian species, mostly fruiting during the dry season (SEGHIERI et al. 2009) and therefore a good supplement during the non-agricultural season. However, despite its drought tolerance, it was classified as strong-ly declining in our survey and might be not sufficiently available in the future. Likewise, OKIA et al. (2011) found $B$. aegyptiaca to be declining in Uganda due to land clearings and increased grazing pressure.

Interestingly, the substitution pattern of Tamarindus indica differed to those of the other nine most cited wild food species as it was mainly substituted by an exotic tree (lemon) and by two native species (Piliostigma sp.) that were not mentioned as substitutes for the other important species. In terms of quantities, the two Piliostigma species seem to be "good" and available substitutes as they were not very important wild food species according to our interviews. However, in terms of qualities i.e. acidic flavour, lemons might be a better substitute for tamarind than the two Piliostigma species, but being on the same time more expensive.

The very low number of cited substitutes for B. costatum indicates that the impact on the traditional cuisine could 
be high in case of species decrease or deficit. This is less the case for all other products since more substitutes were known.

\subsubsection{Relation of the choice in substitution to socio-eco- nomic-characteristics}

For the majority of the most important wild food species, the substitution choice did not depend on socio-economic characteristics. This indicates that knowledge is more or less commonly shared among the informants, irrespective of age, ethnicity, education, village origin, income and farmland size. Accordingly, Sop et al. (2012) showed that the use of Balanites aegyptiaca did not differ between different ethnic groups in the sub-Sahel of Burkina Faso. SchumanN et al. (2011) also found no distinct influence of household characteristics on knowledge distribution of the multipurpose tree species Anogeissus leiocarpa. However, for four species, substitution preferences depended on socioeconomic characteristics.

Regardless of the similar characteristics of the villages, substitution preferences for three wild food species (Lannea microcarpa, Tamarindus indica, Vitellaria paradoxa) differed. One reason can be that more information was shared within villages than across villages. Another reason might be the access to different wild food species due to slight differences in precipitation between the villages. Even though both villages are situated in the North Sudanien vegetation zone, Kompienbiga is more humid, situated at the border to the South Sudanien zone. Similarly, LYKKE et al. (2004) and Segnon \& Achigan-Dako (2014) showed that food use preferences in the Sahel and Benin depend on village, in the same and in different phytogeographical regions, respectively.

Concerning differences between ethnicity, Parkia biglobo$s a$ was the only species whose substitution pattern differed. The autochthon Gourmantché knew twice as many substitution species compared to the migrated ethnic groups. A study in south-western Burkina Faso also found ethnicity to have an impact on choice of substitution for three high value NTFP species (KABORÉ et al. 2015).

Regarding differences between income groups, substitution choice for $V$. paradoxa was more diverse for the poor and medium poor compared to the less poor ("richer") households. Owning less farmland, the access to the parkland tree $V$. paradoxa was usually lower for poorer households and therefore knowledge on substitutes was more diverse. The second most cited substitute for the poor and medium income groups was Diospyros mespiliformis and P. biglobosa for the less poor group. Since $P$. biglobosa is also a parkland tree, spared from field clearings, whereas D. mespiliformis is rather found in the savanna woodland, the same explanation pattern applies.

The investigated difference of substitution choice of L. microcarpa for households owning different farmland sizes can be explained in the same manner: Respondents holding more farmland cited $V$. paradoxa more often as substitute than households with less farmland available.

\section{CONCLUSION}

Knowledge on useful wild food species is profound and diverse in the study area. Concurrently, our results show that all species are declining in numbers, of which some contribute considerably to wild food income. In terms of biodiversity and nature protection in general, management recommendations should therefore focus on the whole ecosystem, rather than on only single species. However, to prevent negative economic impacts on livelihoods, management and protection strategies focusing especially on the economically most important species are additionally needed.

Generally, people in the study area are potentially able to counteract decline or absence of wild food by using a variety of substitutes. Substitutes are mainly native species, mostly belonging to the list of the ten most cited wild food species. Decline of one species might therefore increase the pressure on other native food species. Thus, the necessity to protect and sustainable manage native wild food species in woodland savanna and on fields/fallows is reinforced. Moreover, substitution choice is relatively conform between households of different characteristics. The combination of these results shows that maintaining the most important wild food species is crucial for all households irrespective of their characteristics.

\section{ACKNOWLEDGMENTS}

We acknowledge the funding of the project by UNDESERT (EU FP7 243906): "Understanding and combating desertification to mitigate its impact on ecosystem services", financed by the European Commission, Directorate General for Research and Innovation, Environment Program. We thank the Ministry of Scientific Research and Innovation of Burkina Faso for research permit and all respondents for participation in the survey. In addition, we thank Lardia Thiombiano for assistance and translation as well as Yvonne Bachmann for the compilation of the map

\section{REFERENCES}

Agrawal A, Cashore B, Hardin R, Shepherd G, Benson C, Miller D (2013): Economic constributions of forests. Background Paper 1 prepared fo the United Nations Forum for Forests.

Angelsen A, Wunder S (2003): Exploring the forest poverty link: Key concepts, issues and research implications. CIFOR Occas. Pap. 70.

Belcher BM (2003): What isn't an NTFP? Int. For. Rev. 5, 161-168.

CIA (2009): The world factbook [WWW Document]. URL https://www.cia.gov/library/publications/the-world-factbook/geos/uv.html

CIFOR (2011): Forests and non-timber forest products. CIFOR fact sheets [WWW Document]. URL http://www.cifor. org/Publications/Corporate/FactSheet/ntfp.htm

Cooper PJM, Dimes J, Rao KPC, Shapiro B, Shiferaw B, Twomlow S (2008): Coping better with current climatic variability in the rain-fed farming systems of sub-Saharan Africa: An essential first step in adapting to future climate change? Agric. Ecosyst. Environ. 126, 24-35.

DeAton A (1982): Inequality and needs: Some experimental results for Sri Lanka. Popul. Dev. Rev. 8, 35-49.

Djossa BA, Fahr J, Wiegand T, Ayihouénou BE, Kalko EK, SInsIn B (2008): Land use impact on Vitellaria paradoxa C.F. Gaerten. stand structure and distribution patterns: 
a comparison of Biosphere Reserve of Pendjari in Atacora district in Benin. Agrofor. Syst. 72, 205-220.

Gebauer J, El-Siddig K, Ebert G (2002): Baobab (Adansonia digitata $\mathrm{L}$.): A review on a multipurpose tree with promising future in the Sudan. Gartenbauwissenschaft 67, $155-160$.

HAARMEYer DH, Schumann K, Bernhardt-RömermanN M, Wittig R, Thiombiano A, Hahn K (2013): Human impact on population structure and fruit production of the socio-economically important tree Lannea microcarpa in Burkina Faso. Agrofor. Syst. 87, 1363-1375.

Heubach K, Wittig R, Nuppenau EA, Hahn K (2011): The economic importance of non-timber forest products (NTFPs) for livelihood maintenance of rural west African communities: A case study from northern Benin. Ecol. Econ. 70, 1991-2001.

Heubach K, Wittig R, Nuppenau EA, Hahn K (2013): Local values, social differentiation and conservation efforts: The impact of ethnic affiliation on the valuation of NTFPspecies in Northern Benin, West Africa. Hum. Ecol. 41, 513-533.

Heubes J, Heubach K, Schmidt M, Wittig R, Zizka G, NuPPENAU EA, HAHN K (2012): Impact of future climate and land use change on non-timber forest product provision in Benin, West Africa: Linking niche-based modeling with ecosystem service values. Econ. Bot. 66, 383-397.

Jama BA, Mohamed AM, Mulatya J, NuUi AN (2008): Comparing the "Big Five": A framework for the sustainable management of indigenous fruit trees in the drylands of East and Central Africa. Ecol. Indic. 8, 170-179.

Kaboré SA, Schumann K, Hien M, Hahn K, Nacro HB (2015): Stratégies d'adaptation à la réduction des services écosystémiques: cas des potentialités de substitution de trois espèces forestières dans le Sud-Ouest du Burkina Faso. Int. J. Biol. Chem. Sci. 9, 1194-1208.

Kalaba FK, Quinn CH, Dougill AJ (2013): Contribution of forest provisioning ecosystem services to rural livelihoods in the Miombo woodlands of Zambia. Popul. Environ. 35, 159-182.

Kronborg M, Ilboudo JB, Bassolé IHN, Barfod AS, RAVN HW, LYKKE AM (2014): Correlates of product quality of soumbala, a West African non-timber forest product. Ethnobot. Res. Appl. 12, 25-37.

LYKKE AM (1998): Assessment of species composition change in savanna vegetation by means of woody plants' size class distributions and local information. Biodivers. Conserv. 7: 1261-1275.

LYKKe AM, Kristensen MK, Ganaba S (2004): Valuation of local use and dynamics of 56 woody species in the Sahel. Biodivers. Conserv. 13: 1961-1990.

Malleson R, Asaha S, Egot M, Kshatriya M, Marshall E, Obeng-Okrah K, Sunderland T (2014): Non-timber forest products income from forest landscapes of Cameroon, Ghana and Nigeria - an incidental or integral contribution to sustaining rural livelihoods? Int. For. Rev. 16: 261-277.

Nacoulma BMi, Schumann K, Traoré S, BernhardTRömermann M, Hahn K, Wittig R, Thiombiano A (2011): Impacts of land-use on West African savanna vegetation: a comparison between protected and communal area in Burkina Faso. Biodivers. Conserv. 20: 3341-3362.

Okia CA, Agea JG, Kimonda JM, Abohassan RAA, OKIROR P, Obua J, TeKLehaimanot Z (2011) Uses and manage- ment of Balanites aegytiaca in drylands of Uganda. Res. J. Biol. Sci. 6: 15-24.

PATTANAYAK SK, SiLls EO (2001): Do tropical forests provide natural insurance? The microeconomics of non-timber forest product collection in the Brazilian Amazon. Land Econ. 77: 595.

Pouliot M (2012): Contribution of "Women's Gold" to West African livelihoods: The case of Shea (Vitellaria paradoxa) in Burkina Faso. Econ. Bot. 66: 237-248.

Sala oE, Chapin FS, Armesto JJ, Berlow El, BloomField J, Dirzo R, Huber-SANWALd E, HuENNEKe LF, JACKson RB, Kinzig A, Leemans R, Lodge DM, Mooney HA, Oesterheld M, Poff NL, Sykes MT, Walker BH, Walker M, WALL DH (2000): Global biodiversity scenarios for the year 2100. Science (80-. ). 287: 1770-4.

SChreCKEnBerg K (1999): Products of a managed landscape: non-timber forest products in the parklands of the Bassila region, Benin. Glob. Ecol. Biogeogr. 8: 279-289.

Schumann K, Wittig R, Thiombiano A, Becker U, Hahn $\mathrm{K}$ (2011): Uses and management strategies of the multipurpose tree Anogeissus leiocarpa in eastern Burkina Faso. Flora Veg. Sudano-Sambesica 14: 10-19.

Schumann K, Wittig R, Thiombiano A, Becker U, Hahn K (2012): Uses, management, and population status of the baobab in eastern Burkina Faso. Agrofor. Syst. 85, 263-278.

Seghieri J, Do FC, Devineau J, Fournier A (2009): Phenology of woody species along the climatic gradient in west tropical Africa, in: Zhang, D.X. (Ed.), Phenology and Climate Change. pp. 143-178.

Segnon AC, Achigan-Dako EG (2014): Comparative analysis of diversity and utilization of edible plants in arid and semi-arid areas in Benin. J. Ethnobiol. Ethnomed. 10, 80

Shackleton CM, PANDEY AK (2014): Positioning non-timber forest products on the development agenda. For. Policy Econ. 38: 1-7.

Sop TK, Oldeland J, Bognounou F, Schmiedel U, ThIOMBIANO A (2012): Ethnobotanical knowledge and valuation of woody plants species: A comparative analysis of three ethnic groups from the sub-Sahel of Burkina Faso. Environ. Dev. Sustain. 14: 627-649.

Turner RK, Paavola J, Cooper P, Farber S, Jessamy V, Georgiou S (2003): Valuing nature: Lessons learned and future research directions. Ecol. Econ. 46: 493-510.

UNDP (2014): Human Development Report 2014, sustaining human progress: Reducing vulnerabilities and building resilience. United Nations development Programme, New York, USA.

Vodouhê F, Coulibaly O, Greene, C, Sinsin, B (2009): Estimating the local value of non-timber forest products to Pendjari Biosphere Reserve dwellers in Benin. Econ. Bot. 63: $1-16$.

WeZel A, RATH T (2002): Resource conservation strategies in agro-ecosystems of semi-arid West Africa. J. Arid Environ. 51: 383-400.

Zizka A, Thiombiano A, Dressler S, Nacoulma BM, Oú́draogo A, OuÉdraogo I, OuÉdraogo O, Zizka G, HAHN K, Schmidt M (2015): Traditional plant use in Burkina Faso (West Africa): A national-scale analysis with focus on traditional medicine. J. Ethnobiol. Ethnomed. 11: 9. 